\title{
RANCANG BANGUN ALAT UNTUK MENENTUKAN KADAR ANTOSIANIN PADA BERAS MERAH BERBASIS MIKROKONTOLLER ARDUINO UNO
}

\author{
Hasmah $\mathbb{D}^{1)}$ dan Suwarmiyati $\mathbb{B}^{2)}$ \\ ${ }^{1,2}$ Teknologi Elektromedik, Politeknik Kesehatan Muhammadiyah Makassar \\ 1,2, J1 Ratulangi No. 101, Makassar,90135 \\ E-mail : hasmahatem@gmail.com ${ }^{1)}$, suwarmiyati.imb@gmail.com ${ }^{2)}$
}

\begin{abstract}
ABSTRAK
Antosianin merupakan pigmen alami yang menyebabkan warna merah, ungu dan biru. pada bunga, buah, daun, dan bijibijian. Antosianin termasuk golongan flavonoid berperan sebagai antioksidan yang menangkap radikal bebas yang dapat mencegah penyakit kanker dan tumor. Penelitian ini akan memadukan dua disiplin ilmu yaitu ilmu kimia dan elektro yang akan diaplikasikan pada bidang kesehatan. Pada penelitian ini dirancang sebuah alat yang menggunakan sensor TCS 3200 dan arduino Uno sebagai mikrokontroler. Luaran dari pengukuran ini merupakan data frekuensi warna merah, hijau, dan biru (RGB) yang merupakan warna dasar dari spektrum warna. Prinsip kerja rancangan alat ini pada dasarnya sama dengan spektrofotometer yang mengukur absorbansi panjang gelombang cahaya tertentu pada suatu larutan. Sampel yang digunakan adalah beras merah Maros yang telah di maserasi selama 24 jam dengan variasi pelarut yaitu pelarut aquades, metanol, etanol, aquades- $\mathrm{HCl} 1 \%$, methanol- $\mathrm{HCl} 1 \%$, dan etanol- $\mathrm{HCl} 1 \%$. Hasilnya pengukuran konsentrasi dengan rancangan alat berturut-turut adalah : $0,80 \mathrm{mg} / 100 \mathrm{~g}, 0,98 \mathrm{mg} / 100 \mathrm{~g}, 0,90 \mathrm{mg} / 100,0,82 \mathrm{mg} / 100 \mathrm{~g}, 1,02 \mathrm{mg} / 100 \mathrm{~g}$, dan 0,94 $\mathrm{mg} / 100 \mathrm{~g}$. Hasil pembacaan rancangan alat dibandingkan hasilnya dengan spektroskop UV-VIS. Diharapkan setelah penelitian, rancangan alat ini dapat dijadikan instrument pengukuran awal sebelum analisis colourimetri untuk mengetahui kandungan gizi suatu bahan pangan khususnya antosianin.
\end{abstract}

Kata Kunci: Beras Merah, Sensor RGB, Antosianin

\section{PENDAHULUAN}

Seiring dengan tingginya paparan radikal bebas yang berasal dari radiasi, asap rokok, polusi kendaraan dan pabrik, pestisida, obat-obatan, dan berbagai sumber radikal bebas lainnya, risiko kesehatan pada manusia turut meningkat. Jumlah radikal bebas dan antioksidan dalam tubuh yang tidak seimbang mengakibatkan terjadinya stress oksidatif (Thamrin dkk., 2017). Berbagai penyakit akan timbul akibat stress oksidatif tersebut seperti penyakit kardiovaskular, kanker, penyakit respirasi kronis, dan diabetes melitus (Abdullah, 2017).

Untuk meminimalkan risiko kesehatan yang ditimbulkan oleh paparan radikal bebas dapat dilakukan dengan menerapkan gaya hidup sehat dan diet, misalnya mengonsumsi makanan yang kaya senyawa bioaktif. Senyawa bioaktif pada pangan dapat bertindak pada berbagai aktivitas biologis, misalnya sebagai antioksidan dalam tubuh. Peranan pangan saat ini tidak hanya sebagai pemenuhan kebutuhan gizi dan pemberi rasa kenyang tetapi juga diharapkan bermanfaat bagi kesehatan (Setiawati dkk., 2017). Salah satu jenis pangan yang sangat dekat dengan masyarakat Indonesia adalah beras. Beras merupakan kelompok serealia yang mengandung karbohidrat tinggi dan menjadi sumber utama kalori. Ketersediaan bahan pangan dengan indeks glikemik rendah merupakan masalah utama bagi penduduk Indonesia. Makanan pokok bagi sebagian besar penduduk Indonesia adalah nasi, sementara nasi memiliki IG sebesar $92 \pm 6$, yang termasuk IG tinggi (Diyah dkk., 2018) .Nasi putih sebagai makanan pokok cenderung dihindari bagi orang yang sedang berdiet dan penderita penyakit diabetes. Sebagian masyarakat ada sudah beralih mengkonsumsi nasi dari beras merah sebagai pilihan untuk memenuhi kecukupan gizi dan memberi manfaat kesehatan selain sebagai sumber kalori. Beras merah banyak dijual sebagai beras fungsional dan dikonsumsi oleh penderita diabetes dan penyakit jantung koroner. (Priska dkk., 2018).

Beras Merah Maros merupakan salah varietas yang digemari oleh konsumen karena menghasilkan nasi yang pulen. Sudah banyak penelitian tentang kandungan gizi pada beras merah di Indonesia. Penelitian tentang beras merah inspirasi manusia untuk menjalankan pola hidup sehat dan mendorong pelaku usaha kecil dan menengah untuk memproduksi suatu olahan makanan dari beras merah yang sehat dan bergizi seperti flake (Setiawati dkk., 2017). Olahan beras merah pun mulai marak dikonsumsi seperti tepung cake, dan flake dari beras merah. Beras merah Maros sudah diolah menjadi tepung yang mulai digemari sebagai bahan bubur dan bahan untuk membuat cake walaupun belum ada label kandungan gizi yang tertera pada produk. Hal ini disebabkan minimnya informasi tentang kandungan gizi suatu produk bahan pangan dan untuk memperoleh informasi prosedurnya harus melalui uji klinis di BPOM. 
Nutrisi beras merah sebagian terletak di lapisan kulit luar (aleuron) yang mudah terkelupas pada saat penggilingan (Swasti dkk., 2017).Beras merah pada bagian aleuron nya mengandung gen yang memproduksi antosianin (Arifin dkk., 2019). Selanjutnya dijelaskan bahwa antosianin pada beras berpigmen mampu berperan dalam berbagai aktivitas biologis dalam tubuh. Penelitian tentang antosianin sebagai pewarna alami (Amanda \& Kurniaty, 2017) menjelaskan bahwa antosianin termasuk 2golongan flavonoid yang menjadi pewarna pada sebagian besar tanaman, yaitu warna biru, ungu dan merah. Metode untuk memperoleh antosianin dilakukan dengan metode ekstraksi dengan berbagai pelarut seperti metode ekstraksi antosianin pada bunga rosella (Dwi Utari dkk., 2017), dijelaskan bahwa Antosianin dari bunga rosella dapat diambil dengan menggunakan teknik ekstraksi. Dalam bentuk larutan kurang stabil hingga perlu dilakukan pengeringan menjadi serbuk. Teknik ekstraksi yang biasa dilakukan untuk mengeluarkan antosianin dari buah, bunga, daun, maupun biji-bijian adalah miserasi atau perendaman seperti pada penelitian (Armanzah \& Hedrawati, 2016) yang menjelaskan bahwa sifat fisika dan kimia dari antosianin dilihat dari kelarutan antosianin larut dalam pelarut polar seperti metanol, aseton, atau kloroform, terlebih sering dengan air dan diasamkan dengan asam klorida atau asam formiat. Pada penelitiannya menggunakan etanol $96 \%$ untuk maserasi ubi jalar.

Kadar antosianin pada beras merah juga menarik perhatian untuk diteliti sebagai salah satu alternatif makanan pokok yang kaya nutrisi penting bagi kesehatan terutama pada beras merah padi lokal. Varietas padi lokal yang berwarna merupakan plasma nutfah berharga yang dapat berperan sebagai pangan fungsional di masa depan. Padi warna memiliki kandungan antosianin yang berfungsi sebagai komponen nutrien bioaktif, yang dinamakan antioksidan. Antioksidan yang dimaksud adalah antosianin. Antosianin pada beras warna mengandung acetylated procyanidins, yang dilaporkan memiliki aktivitas radikal bebas (Armanzah \& Hedrawati, 2016). Penelitian yang serupa mengenai olahan beras merah (Anggraini dkk., 2017) tentang aktivitas antioksidan, kadar polifenol, antosianin serta karakteristik fisik sponge cake dari berbagai varietas beras merah, beras hitam, dan beras putih. Penelitian itu melaporkan bahwa kandungan total senyawa fenolik pada beras berpigmen pada beras maupun olahannya lebih besar dibandingkan kandungan total senyawa fenolik beras putih (non pigmented). Manfaat lain dari antosianin adalah sebagai pewarna alami pada makanan (Pigmen dkk., 2021).

Metode yang biasa digunakan untuk melakukan pengujian kadar atau konsentrasi suatu zat di laboratorium adalah colorimetri dengan menggunakan spektrofotometer Uv-Vis,Seperti penelitian tentang kadar antosianin pada buah naga. Panjang gelombang yang digunakan untuk menentukan absorbansi antosianin yaitu 520 - 560 nm (Kwartiningsih dkk., 2016). Kadar
Antosianin berbanding lurus dengan kepekatan warnanya (Maharani dkk., 2020).

Spektrofotometer UV-VIS relatif harganya lebih mahal dan perawatannya pun tidak mudah. Hal ini menjadi alasan untuk menemukan suatu alat yang relatif lebih murah, praktis dan dapat dijadikan instrument pengukuran awal yang pemanfaatannya secara tidak langsung dapat edukasi masyarakat untuk menerapkan pola hidup sehat dengan mengkonsumsi bahan pangan yang telah diketahui kandungan gizinya. Pelaku usaha pun dapat mengetahui informasi gizi tentang produknya secara lebih dini sebelum memulai produksi usahanya.

\section{RUANG LINGKUP}

Dalam penelitian ini permasalahan mencakup:

1. Permasalahan.

Berdasarkan penjelasan sebelumnya, informasi tentang gizi bahan pangan seperti beras merah Maros, khususnya figment antosianin masih minim. Untuk memperoleh informasi tentang kandungan gizi dibutuhkan suatu alat yang praktis dan relatif lebih murah sebagai instrumen pengukuran awal sebelum pengukuran kadar di laboratorium.

2. Batasan-batasan penelitian.

Pada penelitian dirancang instrumen pengukuran kadar antosianin sederhana yang menggunakan sensor warna TCS 3200 atau RGB sensor. Antosianin yang diukur kadarnya dalam bentuk sianidin-3glikosida.

3. Rencana hasil yang didapatkan.

Dengan selesainya penelitian ini diharapkan.

1) Publikasi ilmiah di Jurnal Nasional ter akreditasi dan prosiding seminar ilmiah berskala Nasional

2) Memperkenalkan alat yang dapat digunakan untuk menentukan kadar bukan hanya antosianin pada beras merah tetapi juga kadar larutan lain yang berwarna dengan yang bersifat praktis dengan harga yang terjangkau.

3) Pengayaan bahan ajar dalam bidang kimia klinik dan teknik elektromedik

\section{BAHAN DAN METODE}

Bahan yang digunakan dalam penelitian ini adalah terdiri dari sampel dan bahan-bahan untuk merancang instrumen pengukuran kadar antosianin. Sedangkan metode terdiri dari rancangan alat dan membandingkan hasilnya dengan spektrofotometer UV-VIS.

\subsection{Beras Merah \& Mikrokontroler}

Bahan terdiri dari beras merah Maros dan bahan untuk maserasi, yaitu aquades, metanol 96\%, etanol $70 \%$, dan $\mathrm{HCl} 1 \%$. Antosianin flavonoid. Penampakan fisik beras merah ditunjukkan pada gambar 1: 


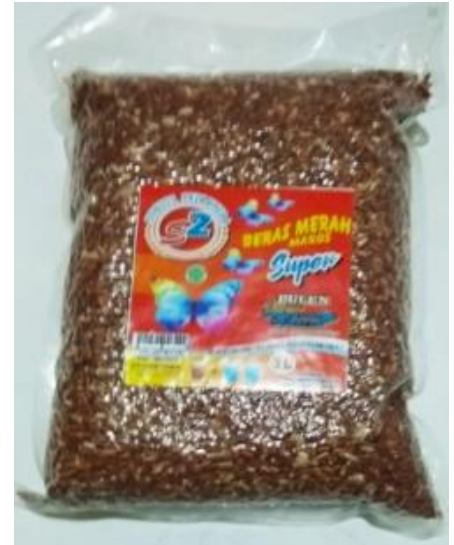

Gambar 1. Beras Merah Maros

(Sumber : Data Primer, 2020)

Senyawa golongan flavonoid termasuk senyawa polar. Sehingga untuk mendapatkan ekstrak antosianin dapat dilakukan dengan mengekstrak beras merah dengan pelarut yang bersifat polar pula seperti air, metanol dan etanol. Senyawa antosianin sangat stabil pada $\mathrm{pH}$ rendah (keadaan asam) jika dibandingkan dengan larutan netral atau alkali, sehingga perlu diberi penambahan larutan $\mathrm{HCl} 1 \%$ yang merupakan larutan asam paling efektif (Nasrullah dkk., 2020). Kestabilan antosianin Sedangkan bahan untuk merancang alat dalam penelitian ini adalah Arduino Uno, RGB sensor TCS 3200,LCD 2x16, Power Suplai Switching Regulator 12 V, Saklar Power, Kabel Jumper, Solder Iron, Solder Suction Besar, dan Timah Solder, box acrylic. Alat yang digunakan untuk merancang alat adalah multitester, solder, tang lancip, tang potong, pingser elektronik, Notebook untuk memodifikasi software arduino Uno, spektrofotometer UV-VIS, rotary evaporator, stirrer magnetik, timbangan digital, dan alat-alat gelas.

Sensor TCS 3200 adalah IC (Integrated Circuit) pengonversian warna cahaya ke frekuensi. Ada dua komponen utama pembentuk IC ini, yaitu fotodioda dan pengonversian arus ke frekuensi. fotodioda pada IC TCS3200 disusun secara array 8 × 8 dengan konfigurasi: 16 fotodioda untuk memfilter warna merah, 16 fotodioda untuk memfilter warna hijau, 16 fotodioda untuk memfilter warna biru, dan 16 fotodioda tanpa filter (Thamrin dkk., 2017). Dijelaskan pula dalam penelitiannya, sensor warna TCS 3200 adalah sensor warna buatan TAOS Parralax. TCS 3200 merupakan produk penyempurnaan dari produk sebelumnya yaitu TCS 230. Perbedaan antara TCS 3200 dan TCS 230 adalah konsumsi arusnya. Bentuk fisik dari sensor warna ditunjukkan dalam gambar 2.

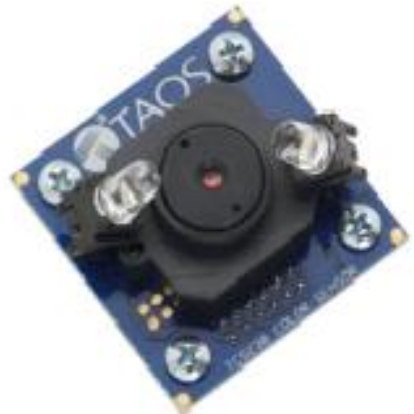

Gambar 2. Sensor TCS3200

(Sumber : Thamrin dkk., 2017)

\subsection{Metode}

Pada dasarnya penelitian ini adalah merancang suatu instrumen pengukuran untuk mengukur kadar antosianin yang prinsipnya sama dengan spektrofotometer UV-VIS. Sampel penelitian yang akan diuji harus melewati tahaptahapan sebagaimana penelitian di laboratorium. Sementara rancangan alat merupakan instrumen pengukuran yang berupa rangkaian komponenkomponen elektronika yang berbasis Arduino Uno sehingga perlu memodifikasi software. Ada empat tahap utama dalam penelitian ini setelah menyiapkan alat dan bahan adalah memodifikasi software arduino Uno, merancang alat, uji sampel beras merah dengan rancangan alat, dan uji sampel dengan spektrofotometer untuk membandingkan hasil dari kedua instrumen. Rancangan alat menggunakan Arduino uno merupakan salah satu jenis rangkaian mikrokontroler yang menggunakan sistem physical computing. Physical computing adalah sebuah sistem atau perangkat fisik dengan menggunakan software dan hardware yang sifatnya interaktif yaitu dapat menerima rangsangan dari lingkungan dan dapat merespons balik. (Thamrin dkk., 2017). Selanjutnya dijelaskan bahwa Arduino Uno terdiri dari mikroprosesor dan dilengkapi dengan oscillator 16 $\mathrm{MHz}$, dan regulator (pembangkit tegangan) 5 volt. Pada papan arduino uno terdapat beberapa pin input dan output yaitu pin 0 hingga 13 digunakan untuk sinyal digital, yang hanya bernilai 0 atau 1. Pin A0 hingga A5 digunakan untuk sinyal analog seperti gambar 3.

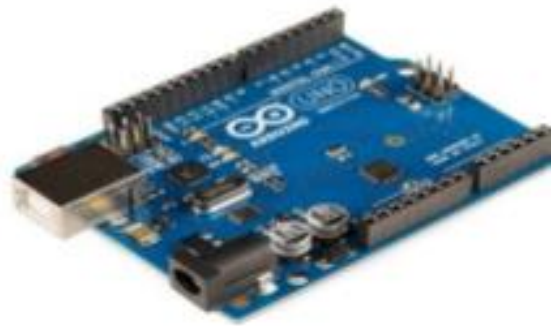

Gambar 3. Arduino Uno

(Sumber: Thamrin dkk., 2017) 


\section{Membuat Software}

Arduino adalah kombinasi dari hardware, bahasa pemrograman dan Integrated Development Environment (IDE). IDE adalah sebuah software yang sangat berperan untuk menulis program, meng-compile menjadi kode biner dan meng-upload ke dalam memory mikrokontroler (Thamrin dkk., 2017). Mikrokontroler Arduino Uno bekerja berdasarkan software yang dirancang. Software biasanya satu paket dengan sensor yang disebut arduino IDE. Software kemudian dimodifikasi sesuai kebutuhan analisis data penelitian. RGB sensor TCS 3200 membaca sampel berdasarkan warna. Pada tampilan laptop muncul angka-angka berdasarkan warna merah, hijau, dan biru.

\section{Merancang alat $F$}

Sumber cahaya digunakan yaitu LED berfungsi sebagai fitur notifikasi visual dengan beberapa warna untuk jarak dan tujuan tertentu (Mulyani, 2018)( LED yang digunakan adalah LED putih yang satu paket dengan RGB sensor TCS 3200 dan sampel yang digunakan dalam penelitian ini yaitu hasil ekstrak maserasi beras merah. Cahaya dari LED akan diteruskan oleh sampel yang ada pada kuvet atau tabung reaksi. Pada rancangan alat ini, jarak diatur sedemikian rupa sehingga semua cahaya dari LED mengenai kuvet. Sebagian cahaya ini akan diserap (absorb) oleh sampel dan sebagian lagi akan diteruskan. Cahaya yang diteruskan ini akan dibaca oleh RGB sensor TCS 3200 dan akan mengubah sinyal spektrum cahaya menjadi sinyal yang akan dibaca oleh mikrokontroler arduino Uno. Data dari arduino Uno kemudian diproses dengan menggunakan bahasa program arduino IDE yang telah dimodifikasi.

\section{Membuat rangkaian alat}

Sensor yang digunakan adalah sensor warna RGB TCS 3200 berisi photodioda sehingga diperlukan sumber cahaya untuk mendeteksi warna. Empat LED putih terhubung di sekitar sensor. Selain photodiode terdapat pengonversian arus ke frekuensi. Keluaran dari sensor ini sendiri berupa output digital yang berbentuk pulsa pulsa hasil pembacaan warna RGB (Jefriyanto dkk., 2017). Arduino Uno langsung dihubungkan dengan sensor. Arduino Uno terhubung degan laptop sehingga pembacaan RGB sensor TCS 3200 terbaca di laptop.

\section{Uji Coba Rancangan Alat tahap pertama}

Pada tahap ini diadakan uji coba kemampuan alat untuk membaca sampel yang berjumlah 30 gram yang telah direndam demgan $150 \mathrm{~mL}$ pelarut aquades. Untuk mengentalkan sampel yang digunakan untuk uji coba digunakan rotary evaporator selama 30 menit. Diskusi terjadi untuk menentukan posisi kuvet dan tempat dudukan kuvet agar lampu LED sensor terfokus mengenai kuvet yang berisi sampel.

\section{Uji Coba Alat tahap kedua}

Jumlah sampel yang digunakan sama dengan uji coba alat yang pertama tetapi menggunakan tiga jenis pelarut. Pada tahap ini kami mengupayakan pembacaan rancangan alat menjadi nol jika tidak ada sampel.

\section{Persiapan Ekstraksi Maserasi Sampel Beras Merah (Oryza)}

Metode ekstraksi yang digunakan dalam penelitian ini yaitu maserasi. Beras merah (Oryza nivara) yang digunakan sebagai sampel adalah beras merah Maros sebagai hasil produksi petani Kabupaten Maros. Beras merah dibersihkan dari pengotor dan menimbang sebanyak 100 gram selanjutnya dicuci di bawah air mengalir sampai bersih kemudian tirisan. Maserasi dilakukan dengan menggunakan pelarut metanol, methanol- $\mathrm{HCl} 1 \%$ etanol, etanol- $\mathrm{HCl} \%$, dan air. Beras merah dalam bentuk utuh (bulir) pada suhu 25oC.Perendaman dilakukan dalam $300 \mathrm{~mL}$ pelarut selama 24 jam.

\section{Pengentalan sampel dengan Stirrer magnetik}

Setelah maserasi selama 24 jam, Sampel disaring kemudian dikentalkan dengan magnetik stirrer yang telah diatur suhunya. Suhu optimal dan stabilitas ekstrak pigmen antosianin berada pada rentang suhu 400C- 500 $\mathrm{C}$ dengan lama pemanasan antara 30, 45 dan 60 menit (Nasrullah dkk., 2020). Suhu Magnetik stirrer diatur menjadi $560 \mathrm{C}$ selama 30 menit untuk masing-masing sampel dapat dilihat pada gambar 4 dan 5 .

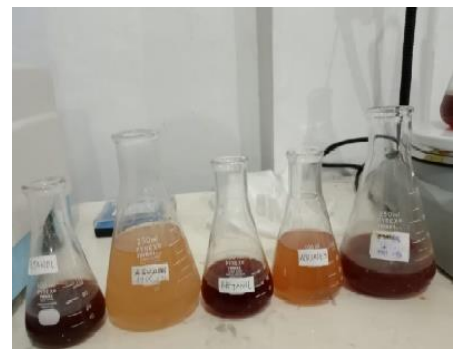

Gambar 4. Sampel Sebelum Dikentalkan Dengan Magnetik Stirrer

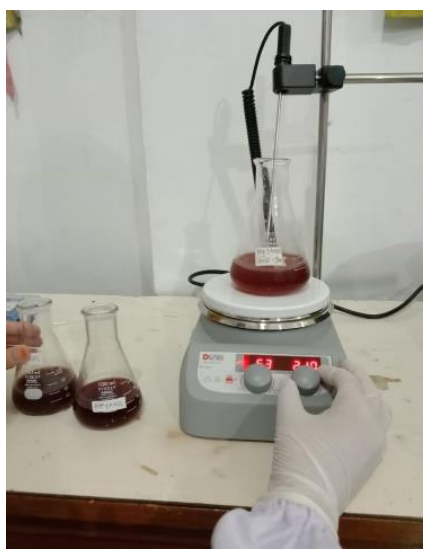

Gambar 5. Sampel Setelah Dikentalkan Dengan Menggunakan Stirrer Magnetik 
8. Menyusun alat secara terpadu

Setelah rangkaian sudah dibuat, komponenkomponen dihubungkan kemudian dites apakah tiap bagian sudah berfungsi atau belum. Setelah selesai alatalat ini akan disusun dalam box acrylic. Hasil rancangan alat lengkap dengan box acrylic diperlihatkan pada gambar 6.

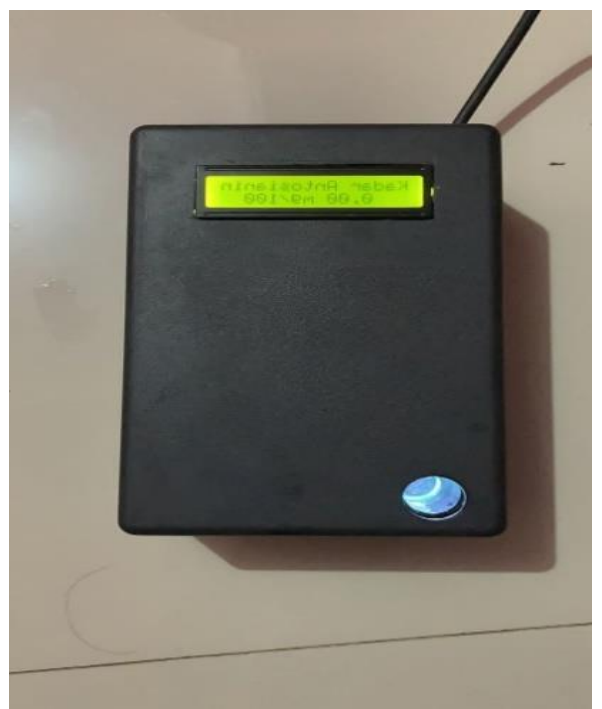

Gambar 6. Rancangan Alat Penentuan Kadar Antosianin Lengkap Dengan Box Acrylic

9. Uji Sampel dengan rancangan Alat

Rancangan alat dihubungkan dengan sumber tegangan sehingga dalam posisi ON. Sebanyak $5 \mathrm{~mL}$ sampel dalam tabung reaksi dimasukkan kedalam tempat tabung reaksi pada rancangan alat. Layar LCD menampilkan hasil pembacaan rancangan alat. Hasil rancangan alat lengkap dengan bagian-bagiannya diperlihatkan pada gambar 7 .

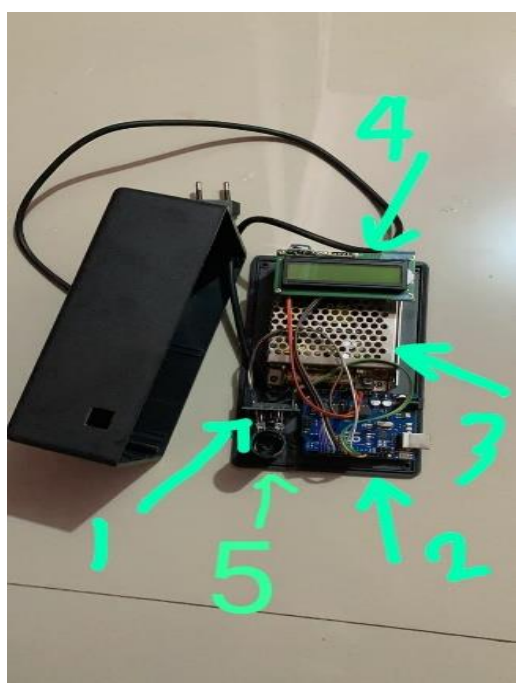

Gambar 7. Rancangan Alat Penentuan Kadar Antosianin Beserta Bagian-Bagiannya
Keterangan Gambar 7

1. RGB adalah Sensor TCS 3200

2. Arduino Uno

3. Power supply

4. LCD $2 \times 16$

5. Tempat sampel.

Penentuan kadar antosianin dimulai dengan metode ekstraksi terhadap beras merah. Proses ekstraksi beras merah menggunakan metode maserasi. Prinsipnya adalah mengekstrak senyawa aktif yang dapat larut dalam pelarut berdasarkan tingkat kepolaran masing-masing pelarutnya like dissolves like (Khopkar, 2008). Beras merah (Oryza nivara) sebagai hasil produksi petani Kabupaten Maros. Beras merah dibersihkan dari pengotor dan menimbang sebanyak 100 gram selanjutnya dicuci di bawah air mengalir sampai bersih kemudian tiris. Maserasi dilakukan dengan menggunakan pelarut metanol, methanol- $\mathrm{HCl} 1 \%$ etanol, etanol- $\mathrm{HCl} \%$, dan air. Beras merah dalam bentuk utuh (bulir) pada suhu $250 \mathrm{c}$. Perendaman dilakukan dalam $300 \mathrm{~mL}$ pelarut selama 24 jam. Perendaman berbagai pelarut dimaksudkan untuk mengetahui pelarut yang menghasilkan antosianin tertinggi (Anggraeni dkk., 2018).

Setelah maserasi selama 24 jam, Sampel disaring kemudian dikentalkan dengan magnetik stirrer yang telah diatur suhunya. Suhu optimal dan stabilitas ekstrak pigmen antosianin berada pada rentang suhu 400C- 500 $\mathrm{C}$ dengan lama pemanasan antara 30, 45 dan 60 menit (Nasrullah dkk., 2020).Hasil pengukuran kadar antosianin ditunjukkan seperti tabel 1 .

Tabel 1. Hasil Pengukuran Kadar Antosianin dengan Rancangan Alat

\begin{tabular}{|l|l|}
\hline Pelarut & $\begin{array}{l}\text { Kadar Antosianin } \\
\text { (mg/100 gr) }\end{array}$ \\
\hline Aquades & 0,80 \\
\hline Metanol & 0,98 \\
\hline Etanol & 0,90 \\
\hline Aquades - $\mathrm{HCl} \mathrm{1 \%}$ & 0,82 \\
\hline Metanol - $\mathrm{HCl} 1 \%$ & 1,02 \\
\hline Etanol - $\mathrm{HCl} \mathrm{1 \%}$ & 0,94 \\
\hline
\end{tabular}

10. Uji Sampel dengan Spektrofotometer UV-VIS

Setelah sampel diuji dengan alat yang telah dibuat maka sampel di uji dengan spektrofotometer. Spektrofotometri merupakan metode standar yang digunakan untuk menentukan validitas alat yang dirancang pada penelitian ini Absorbansi diukur pada panjang gelombang 510-700 nm. Absorbansi tertinggi muncul pada panjang gelombang $545 \mathrm{~nm}$, yakni maserasi beras merah dengan pelarut methanol-HCl $1 \%$.

Spektrofotomer merupakan metode standar yang digunakan untuk menentukan validitas alat yang dirancang pada penelitian ini. Sebelum uji coba alat untuk menentukan kadar antosianin terlebih dahulu sampel hasil maserasi beras merah diuji dengan menggunakan spektrofotometer. Absorbansi sampel 
diukur pada panjang gelombang 510-700 nm. Hasil pengukuran absorbansi sampel beras merah ditunjukkan pada tabel 2 .

Tabel 2. Kadar Antosiani Hasil Spektrofotometer UV- VIS

\begin{tabular}{|c|c|}
\hline Pelarut & Absorbansi \\
\hline Aquades & 0,559 \\
Metanol & 1,039 \\
Etanol & 1,068 \\
Aquades + $\mathrm{HCl} \mathrm{1 \%}$ & 0,888 \\
Metanol + $\mathrm{HCl} \mathrm{1 \%}$ & 1,084 \\
Etanol + $\mathrm{HCl} \mathrm{1 \%}$ & 1,068 \\
\hline
\end{tabular}

Konsentrasi dihitung dengan menggunakan rumus (Anggraeni VJ, 2018), kadar antosianin (mg/100g) (1).

$$
\frac{\mathrm{A} \times \mathrm{MW} \times \mathrm{DF} \times \mathrm{V} \times 100}{\varepsilon \times L \times W}
$$

Dimana : A adalah absorbansi sampel, MW adalah berat molekul dihitung sebagai sianidin-3glukosida, MW = 449,2) (g/mol), DF adalah faktor kelarutan, V adalah volume larutan induk sampel $(\mathrm{mL}), \mathrm{W}$ adalah berat ekstrak sampel (gram), L adalah lebar kuvet $=1 \mathrm{~cm}, \varepsilon$ adalah absorptivitas molar sianidin-3- glukosida = 26.900 dan 100 merupakan faktor konversi untuk perhitungan dalam mg/100 gram sampel (mol.cm).

\section{PEMBAHASAN}

Dari hasil rancangan alat, maserasi dengan pelarut metanol yang diasamkan dengan $\mathrm{HCl} 1 \%$ menghasilkan konsentrasi yang tertinggi yakni 1,02 mg dalam 100 gram beras merah Maros. Pada jenis beras merah yang lain diperoleh kadar antosianin $0,1503(\mathrm{mg} / 100 \mathrm{~g})$ dengan pelarut metanol yang telah diasamkan dengan $\mathrm{HCl} 1 \%$ (Anggraeni dkk., 2018). Dengan sampel yang sama dilakukan pengujian lanjut dengan Spektroskop UV-VIS yang menghasilkan absorbansi tertinggi, yakni 1,084 pada panjang gelombang $545 \mathrm{~nm}$ pada sampel yang telah diekstraksi maserasi pelarut methanol - $\mathrm{HCl} 1 \%$.

Penelitian tentang rancang bangun suatu alat berbasis Arduino Uno, hasilnya dibandingkan dengan alat standar. Penelitian tentang rancangan suatu timbangan (Sani \& Maha, 2018),rata-rata persentase tingkat ratarata dihitung dengan persamaan (2)

$$
\begin{aligned}
& \text { E - HPAS } \\
& \sum E=\quad x 100 \% \quad(2) \\
& \text { HPAS }
\end{aligned}
$$

$\sum E$ adalah rata-rata tingkat kesalahan, $\bar{E}$ adalah ratarata pengukuran, HPAS adalah rata-rata hasil pengukuran alat standar.

Hasil pengukuran kadar yang diperoleh melalui rancangan alat dengan hasil yang diperoleh melalui spektrofotometer UV-VIS di bandingan seperti yang ditunjukkan pada tabel 3 .

Tabel 3. Hasil Perbandingan Kadar Antosianin dengan Rancangan Alat dan Spektroskop UV-VIS

\begin{tabular}{|c|c|c|c|}
\hline \multirow{2}{*}{ Pelarut } & \multicolumn{2}{|c|}{ Hasil Pengukuran } & $\begin{array}{c}\text { Error } \\
\text { (mg) }\end{array}$ \\
\cline { 2 - 3 } & $\begin{array}{c}\text { Spektrofotome } \\
\text { ter UV-VIS } \\
\text { (mg/100 gr) }\end{array}$ & $\begin{array}{c}\text { Rancangan } \\
\text { Alat } \\
\text { (mg/100 } \\
\text { gr) }\end{array}$ & \\
\hline Aquades & 0,30 & 0,80 & 0,50 \\
\hline Metanol & 0,60 & 0,98 & 0,38 \\
\hline Etanol & 0,58 & 0,90 & 0,32 \\
\hline $\begin{array}{c}\text { Aquades - } \\
\text { HCl 1\% }\end{array}$ & 0,45 & 0,82 & 0,37 \\
\hline $\begin{array}{c}\text { Metanol -HCl } \\
1 \%\end{array}$ & 0,91 & 1,02 & 0,11 \\
\hline $\begin{array}{c}\text { Etanol - HCl } \\
1 \%\end{array}$ & 0,67 & 0,94 & 0,27 \\
\hline
\end{tabular}

Rata-rata Pengukuran Spektrofotometer UV-VIS = 0,59

Rata-rata pengukuran rancangan alat $=$ 0,91

Rata-Rata Error = 0,33

Dengan memasukkan nilai-nilai tersebut diperoleh rata-rata tingkat kesalahan adalah $33 \%$. Pada penelitian ini hasil penentuan kadar antosianin dengan rancangan alat menunjukkan perbedaan hasil yang diperoleh melalui spektrofotometer UV-VIS. Berdasarkan persamaan (2) terjadi error sebesar $0,33 \mathrm{mg}$ atau $33 \%$. Rancangan alat menghasilkan pengukuran kadar yang lebih besar daripada pengukuran dengan spektrofotometer UV-VIS.

Selanjutnya data-data kadar tersebut baik yang diperoleh melalui rancangan alat maupun dengan spektroskop UV-VIS diolah dengan SPSS 16 dengan analisis regresi curva estimate. Hasilnya seperti gambar 8.

Konsentrasi Spektrofotometer UV-VIS

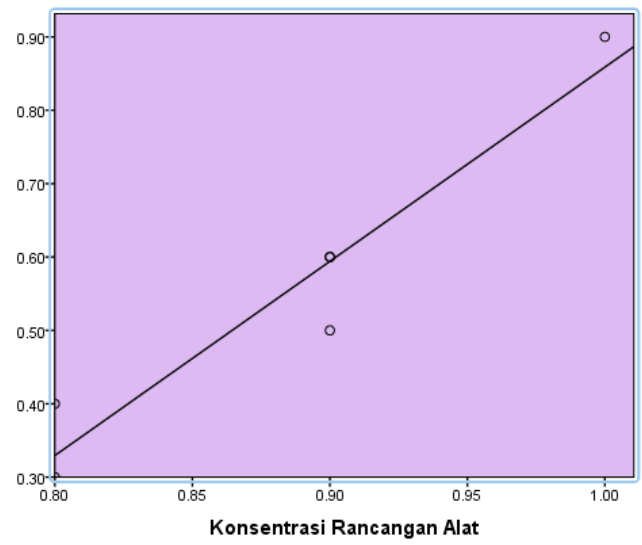

$\stackrel{\circ \text { Observed }}{\text { Linear }}$

Gambar 8. Kurva estimasi Hubungan Konsentrasi Rancangan Alat dengan Kadar Spektroskopi UV-VIS 
Diagram pencar merupakan salah satu alat diagnostik untuk mendapatlan suatu hubungan antara variabel (Saman, Ma'rufi, 2018). Dengan memperhatikan kurva estimasi , tampak data kadar yang diperoleh melalui rancangan alat dan spektrofotometer UV-VIS membentuk garis lurus dan hanya ada dua data yang berpencar.

\section{KESIMPULAN}

Sampel beras merah Maros yang telah di maserasi selama 24 jam dengan variasi pelarut yaitu pelarut aquades, metanol, etanol, aquades- $\mathrm{HCl} 1 \%$, methanol$\mathrm{HCl} 1 \%$, etanol-HCl $1 \%$, diukur kadarnya dengan rancangan alat. Hasil pengukuran kadar dengan rancangan alat berturut-turut hasilnya adalah : 0,80 $\mathrm{mg} / 100 \mathrm{~g}, 0,98 \mathrm{mg} / 100 \mathrm{~g}, 0,90 \mathrm{mg} / 100,0,82 \mathrm{mg} / 100 \mathrm{~g}$, $1,02 \mathrm{mg} / 100 \mathrm{~g}$, dan $0,94 \mathrm{mg} / 100 \mathrm{~g}$.

Data kadar yang diperoleh melalui rancangan alat dan spektrofotometer UV-VIS membentuk garis lurus dengan tingkat kesalahan rancangan alat $33 \%$.

\section{SARAN}

Faktor waktu, bentuk, ukuran, jarak, serta jenis bahan kuvet sampel yang digunakan sangat mempengaruhi hasil pembacaan alat sehingga bagi peneliti selanjutnya harus memperhatikan hal-hal tersebut.

Diharapkan bagi peneliti selanjutnya yang akan menggunakan jenis sampel yang sama sebaiknya menggunakan satu jenis pelarut saja dengan variasi metode.

\section{DAFTAR PUSTAKA}

Abdullah, B. (2017). Peningkatan Kadar Antosianin Beras Merah Dan Beras Hitam Melalui Biofortifikasi / Increasing Anthocyanin of Red and Black Rice through Biofortification. Jurnal Penelitian Dan Pengembangan Pertanian, 36(2), 91. https://doi.org/10.21082/jp3.v36n2.2017.p91-98

Amanda, A., \& Kurniaty, I. (2017). Antosianin Pewarna Alami Minuman Jelly dari Terong Ungu. Seminar Nasional Sains Dan Teknologi 2017, November, h $1-7$.

Anggraeni, V. J., Ramdanawati, L., \& Ayuantika, W. (2018). Penetapan Kadar Antosianin Total Beras Merah (Oryza nivara). Jurnal Kartika Kimia, 1(1), 11-16. https://doi.org/10.26874/jkk.v1i1.11

Anggraini, T., Dewi, Y. K., \& Sayuti, K. (2017). Karakteristik Sponge Cake Berbahan Dasar Tepung Beras Merah, Hitam, dan Putih dari Beberapa Daerah di Sumatera Barat. Jurnal Litbang Industri, $7(2)$, 123. https://doi.org/10.24960/jli.v7i2.3378.123-136

Arifin, A. S., Yuliana, N. D., \& Rafi, M. (2019). Aktivitas Antioksidan Pada Beras Berpigmen dan Dampaknya terhadap Kesehatan. Pangan, 28(1), 11-22.

Armanzah, R. S., \& Hedrawati, T. Y. (2016). Pengaruh waktu maserasi zat antosianin sebagai pewarna alami dari ubi jalar ungu (Ipomoea batatas L. Poir). Seminar Nasional Sains Dan Teknologi, November, 1-10. jurnal.umj.ac.id/index.php/semnastek\%0ApISSN

Diyah, N. W., Ambarwati, A., Warsito, G. M., Niken, G., Heriwiyanti, E. T., Windysari, R., Prismawan, D., Hartasari, R. F., \& Purwanto, P. (2018). Evaluasi Kandungan Glukosa Dan Indeks Glikemik Beberapa Sumber Karbohidrat Dalam Upaya Penggalian Pangan Ber-Indeks Glikemik Rendah. Jurnal Farmasi Dan Ilmu Kefarmasian Indonesia, 3(2), 67. https://doi.org/10.20473/jfiki.v3i22016.6773

Dwi Utari, F., Djaeni, M., Ariani, N., \& Hidayat, R. (2017). Ekstraksi Antosianin dari Kelopak Bunga Rosella (Hibiscus sabdariffa L.) Berbantu Ultrasonik: Tinjauan Aktivitas Antioksidan Ultrasonic Aided Anthocyanin Extraction of Hibiscus sabdariffa L. Flower Petal: Antioxidant Activity. Jurnal Aplikasi Teknologi Pangan, 6(3), 71. https://doi.org/10.17728/jatp.236

Jefriyanto, W., Shein, M. M., Rajak, A., \& Djamal, M. (2017). PROSIDING SNIPS 2017 Rancang Bangun Kolorimeter Berbasis Mikrokontroler Arduino Uno. 87-94.

Kwartiningsih, E., Prastika, A. G., \& Triana, D. L. (2016). Ekstraksi dan Uji Stabilitas Antosianin dari Kulit Buah Naga Super Merah ( Hylocereus costaricensis ). Prosiding Seminar Nasional Teknik Kimia "Kejuangan" Pengembangan Teknologi Kimia Untuk Pengolahan Sumber Daya Alam Indonesia, 1-7. https://core.ac.uk

Maharani, S., Taufik, Y., \& Ikrawan, Y. (2020). Stabilitas Antosianin Nasi Merah Instan Akibat Pengaruh ( Freeze Drying ). Pasundan Food Technology Journal, 7(3), 107-115.

Mulyani, A. (2018). Perancangan Sensor Jarak Aman Kendaraan Bermotor Menggunakan Mikrokontroler Arduino Uno R3. Jurnal Algoritma, 15(1), 22-28. https://doi.org/10.33364/algoritma/v.15-1.22

Nasrullah, Husain, H., \& Syahrir, M. (2020). Pengaruh Suhu Dan Waktu Pemanasan Terhadap Stabilitas Pigmen Antosianin Ekstrak Asam Sitrat Kulit Buah Naga Merah. Jurnal Chemica, 21(2), 150-162.

Pigmen, P., Dari, A., \& Olahan, D. P. (2021). ORGANISMS : JOURNAL OF. 1(1), 12-22.

Priska, M., Peni, N., Carvallo, L., \& Ngapa, Y. D. (2018). Antosianin dan Pemanfaatannya. Cakra Kimia (Indonesian E-Journal of Applied Chemistry), 6(2), 79-97.

Saman, Ma'rufi, A. T. (2018). Pengembangan Video Pembelajaran Matematikamatematika Dalam Meningkatkan Minat Dan Prestasi Belajar Siswa Pada Materi Persamaan Linear Dua Variabel. Pedagogy, 4(1), 1689-1699. http://eprints.umsida.ac.id/id/eprint/1267

Sani, R. A., \& Maha, A. I. (2018). Konstruksi timbangan 
digital menggunakan load cell berbasis arduino uno dengan tampilan lcd (liquid crystal display). Einstein e-journal, 5(2). https://doi.org/10.24114/einstein.v5i2.11837

Setiawati, H., Marsono, Y., \& Sutedja, A. M. (2017). Kadar Antosianin Dan Aktivitas Antioksidan Flake Beras Merah Dan Beras Ketan Hitam Dengan Variasi Suhu Perebusan. Jurnal Teknologi Pangan Dan Gizi, 12(1), 29-38. http://jurnal.wima.ac.id/index.php/JTPG/article/vie w/1478

Swasti, E., Sayuti, K., Kusumawati, A., \& Putri, nurmawanita ekasari. (2017). Kandungan protein dan antosianin generasi F4 turunan persilangan padi merah lokal Sumatera Barat dengan varietas unggul Fatmawati. Jurnal Floratek, 12(1), 49-56.

Thamrin, T., Faiza, D., \& Jasril, I. R. (2017). Rancang Bangun Alat Pengaduk Bubur Otomatis Menggunakan Sensor Suhu Berbasis Arduino Uno. Jurnal Teknologi Informasi Dan Pendidikan, 10(3), 87-100. https://doi.org/10.24036/tip.v10i3.23 